\title{
ESTABELECIMENTOS COMERCIAIS VAREJISTAS NO AGLOMERADO URBANO DE LONDRINA: UM ESTUDO DE CASO
}

\author{
Guilherme Pereira Cocato \\ Universidade Estadual Paulista, Faculdade de Ciências e Tecnologia \\ Presidente Prudente, SP, Brasil \\ guilherme.cocato@unesp.br
}

\begin{abstract}
RESUMO
Considerando a relevância do segmento terciário, com destaque para o comércio e o consumo, em Londrina e seus municípios de entorno, este estudo visa discurtir os principais aspectos teóricos da relação entre as cidades e as atividades comerciais, para depois apreender a espacialização dos estabelecimentos comerciais varejistas no aglomerado urbano de Londrina. Nesse processo, serão utilizados dados da Relação Anual de Informações Sociais, de documentos institucionais do município e da Região Metropolitana de Londrina como todo, e realizados trabalhos de campo para aferir in loco os estabelecimentos comerciais identificados. Entende-se que estes estabelecimentos estão amplamente disseminados pelo aglomerado, em grandes e pequenas concentrações. Enquanto as primeiras são de centros tradicionais já reconhecidos, as segundas se referem aos estabelecimentos de pequeno porte que proporcionam as trocas comerciais fundamentais para a reprodução social dos habitantes urbanos - especialmente em localizações periféricas e condições infraestruturais precárias. Portanto, a presença espacial do consumo e trocas comerciais no meio urbano londrinense são elementos essenciais de estudo para a Geografia Urbana e Econômica.
\end{abstract}

Palavras-chave: Varejo. Centralidades. Londrina. Ambiente construído.

\section{RETAILING COMMERCIAL ESTABLISHMENTS IN LONDRINA URBAN AGGLOMERATE: A CASE STUDY}

\begin{abstract}
Considering the relevance of the tertiary segment, featured for commerce and consumption, in Londrina and its surrounding municipalities, this study aims to discuss the main theoretical aspects of the relationship between cities and commercial activities, and then to apprehend the spatialization of the retail establishments in the urban agglomerate of Londrina. In this process, data will be used from the Annual List of Social Information, institutional documents of the municipality and the Metropolitan Region of Londrina as a whole, and fieldwork will be conducted to assess the identified commercial establishments. It is understood that these establishments are widespread throughout the agglomerate, in large and small concentrations. While the formers are from traditional centers already recognized, the latter refer to small establishments that provide the fundamental trade for the social reproduction of urban residents - especially in peripheral locations and poor infrastructure conditions. Therefore, the spatial presence of consumption and trade in Londrina urban space are essential elements of study for Urban and Economic Geography.
\end{abstract}

Keywords: Retail. Centralities. Londrina. Built environment.

\section{INTRODUÇÃO}

A complexidade das relações socioespaciais entre as cidades e as atividades comerciais é evidente. Ao redor do mundo e ao longo da história, inúmeras formas de comercialização foram praticadas, alavancando e vivificando cidades e os modos de vida nelas presentes. Atraindo consumidores e vendedores de locais distantes. Estas são relações que permanecem ativas nas cidades contemporâneas, especialmente ao se considerar a realidade de urbanização acelerada em países ditos subdesenvolvidos pela lógica capitalista de acumulação.

No capitalismo, a produção de mercadorias é a forma comum de produção social. Nesse sentido, a produção social (de mercadorias) sujeita a sobrevivência humana ao consumo e às trocas comerciais. É por meio destas que o valor do trabalho humano pode ser consumido. Portanto, o consumo liga-se à 
produção, circulação e distribuição de mercadorias, sendo estas necessárias não somente para a manutenção do capitalismo, como também para a reprodução da vida humana no meio urbano. No estado atual de intensificação no consumo e troca de mercadorias, estes são assuntos primordiais para estudos geográficos de cunho econômico e urbano.

No caso de Londrina/PR, esta cidade possui um peso socioeconômico significativo para consumidores de municípios próximos, em escala regional e estadual. Visando aferir a espacialização e a importância dos estabelecimentos comerciais nesse recorte (principalmente os varejistas), esta pesquisa objetiva discutir elementos teórico-metodológicos primordiais na relação das cidades com as atividades comerciais, para depois aferir a realidade concreta dessas formas econômicas nos municípios estudados.

\section{O COMÉRCIO, A CIDADE E O MODO DE VIDA URBANO}

Como parte essencial do presente estudo, é necessária uma visão mais aprofundada sobre as cidades e o modo de vida urbano moderno. Grande parcela da população mundial vive e sobrevive nestes moldes, que têm sofrido intensas transformações ao longo do tempo. Fazendo parte destas transformações, que perduram até hoje, estão as relações comerciais desenvolvidas nas cidades.

Há aproximadamente 150 anos, segundo Oliveira (2001), somente $2 \%$ da população mundial habitava as cidades. Nos anos 1980, o número era de $40 \%$ da população mundial nas cidades, enquanto na América Latina eram 20\%, e no Brasil, 70\%. Giansanti et al. (2003) apresentam que, em 2000, esse porcentual atingiu 47\% no mundo, ou seja, aproximadamente três bilhões de indivíduos viviam nas cidades. Estimase que, entre 2011-2015, a população das cidades ultrapassou 60\% da população mundial.

No início do século XXI, de toda a população brasileira, cerca de 40\% viviam em regiões metropolitanas e cidades médias, comprovando os deslocamentos para aglomerados urbanos maiores e cidades com atração significativa em relação às possibilidades de trabalho e educação (SILVA, 2011). É um movimento populacional próprio do período moderno.

Segundo Wirth (1967), a modernidade é melhor definida na história humana e civilizacional com o advento e crescimento das grandes cidades. Em nenhum local do mundo se afastaram tanto as condições da natureza orgânica original como sob as condições de vida nas cidades, e posteriormente com o modo de vida urbano.

A característica marcante do modo de vida do homem na idade moderna é a sua concentração em agregados gigantescos em torno dos quais está aglomerado um número menor de centros e de onde irradiam as idéias e as práticas que chamamos de civilização (WIRTH, 1967, p. 97).

Dado isso, a gradação de urbanidade em que o mundo contemporâneo se encontra não é definida somente pela proporção de habitantes nas cidades, mas sim pela complexidade das funções e atividades exercidas no e para o meio urbano. Devem ser consideradas as influências que as cidades e o modo de vida urbano exercem sobre a vida social do ser humano, já que tais aspectos são mais impactantes do que a proporção de habitantes urbanos poderia indicar.

Santos (1997) analisa a cidade espacialmente quanto ao processo de produção, sendo que as relações sociais se materializam em um espaço concreto, com a sociedade (re)produzindo espaços diferenciados pelas práticas socioeconômicas. Portanto, a concretização do processo é realizada pela materialização das relações sociais, produtoras dos espaços urbanos. A cidade, em sua evolução histórica e social, mantém relações dialéticas com a sociedade em seu conjunto.

O desenvolvimento das forças produtivas acarreta transformações intensas nos espaços urbanos, e, nos últimos 40 anos, o espaço urbano brasileiro conheceu essas transformações em virtude das modernas tecnologias de comunicação e informação. É o desenvolvimento do chamado meio técnico-científicoinformacional (SANTOS, 1996). Silva (2011) afirma que a modernização se tornou o principal elemento das mudanças nas cidades, com reorganizações socioespaciais a partir da ideologia capitalista dominante.

Como afirma Sposito (1988), a cidade é o lócus preferido da reprodução capitalista, possuindo uma lógica complexa e excludente que se materializa nas relações sociais e conflitos presentes. A paisagem urbana torna-se a espacialização das classes sociais, em suas áreas comerciais, industriais e infraestruturais; nas quais a localização é imprescindível. 
De acordo com Wirth (1967), a cidade não é somente, em graus crescentes, a moradia e local de trabalho do ser humano moderno; mas também é o centro iniciador e controlador da vida econômica, política e cultural, que atrai as localidades mais distantes para o interior de sua esfera de influência, criando redes e interligando atividades e funções socioeconômicas.

\section{A IMPORTÂNCIA DO COMÉRCIO URBANO}

Ao final da década de 1970, estudos de Geografia Econômica, em um viés materialista-histórico e dialético, tomam corpo, priorizando o entendimento do papel do sistema capitalista em conjunto com os estabelecimentos comerciais, assim como a circulação do capital no espaço. A dimensão puramente locacional foi ultrapassada, para uma visão crítica na formação socioespacial a partir dos estabelecimentos comerciais. Assim, o espaço pode ser compreendido como produto e condição para a reprodução social, obedecendo certas normas para as transformações que ocorrem, subordinadas às leis de acumulação do capital e sua busca primordial pelo lucro.

Atualmente, estes princípios de consideração das relações socioeconômicas urbanas locais, em relação com o comércio capitalista globalizado, são essenciais. Silva (2014) propõe o estudo das atividades comerciais, e de reprodução do espaço geográfico, que considere os estabelecimentos comerciais também como sociais, em uma dimensão histórica. Para esses estabelecimentos, as cidades também são lócus privilegiados. Neste sentido, as relações comerciais assumem grande importância para qualquer estudo urbano geográfico.

São as trocas comerciais que constituem o que Harvey (2013) chama de "mundo de aparência" no dia a dia do comércio capitalista, ou "forma fenomenal" da economia presente no cotidiano. Neste processo, os trabalhadores necessitam da produção de mercadorias para satisfação de suas necessidades, ao mesmo tempo em que os produtores dependem de os trabalhadores gastarem seu dinheiro com suas mercadorias. Essa realização se dá por meio das trocas comerciais, demonstrando a importância do comércio varejista para a sobrevivência de ambas as partes.

São relações intrínsecas e dialéticas entre o comércio, o consumo e a cidade, que influenciam na constituição dos estabelecimentos comerciais: o modo de produção da sociedade interfere na criação das formas de troca e nos espaços comerciais, e estes também interferem na reprodução das relações sociais. Como espaço privilegiado das trocas comerciais, a cidade e o meio urbano merecem um enfoque especial.

Portanto, para se falar de cidade, em diversos momentos da história humana, é preciso destacar a existência de um intercâmbio regular, e não ocasional, de mercadorias na localidade urbana. Trata-se de um elemento essencial para a realização de mercadorias, ou seja, sua reconversão à forma dinheiro e a extração do lucro, assim como para o abastecimento dos moradores da cidade. É um mercado, mas não somente isto.

Segundo Weber (1967), o mercado que transforma a localidade genérica em cidade é o mercado que possibilita a satisfação das necessidades diárias da população no próprio local (ou próximo) de residência. Este aspecto define a cidade em termos econômicos, quando se rompe a dependência de feiras e mercados itinerantes, que trazem suas mercadorias de locais distantes durante um período limitado.

Toda cidade no sentido que aqui damos a essa palavra é um "local de mercado", quer dizer, conta como centro econômico do estabelecimento com um mercado local e no qual em virtude de uma especialização permanente da produção econômica, também a população não-urbana se abastece de produtos industriais ou de artigos de comércio ou de ambos e, como é natural, os habitantes da cidade trocam os produtos especiais de suas economias respectivas e satisfazem desse modo suas necessidades (WEBER, 1967, p. 75)

Com a amplificação das trocas comerciais, todos os espaços são atingidos pela complexificação das relações sociais a partir destas atividades:

De qualquer maneira, um belo dia, logicamente, tudo passará pelo mercado, não apenas os produtos da terra ou da indústria, mas também as propriedades fundiárias, o dinheiro, que se movimenta mais depressa do que qualquer outra mercadoria, o trabalho, o esforço dos homens, para não falar do próprio homem (BRAUDEL, 1996, p. 35).

Com a Revolução Industrial, revolucionam-se as atividades econômicas, com uma tendência inerente ao agrupamento e concentração das atividades comerciais, de forma organizacional e administrativa. Espacialmente, os espaços públicos de mercado perdem força para os espaços privados, orientados pelo 
modo de reprodução econômico do sistema capitalista. Tais alterações se acentuam ao longo do século $X X$, culminando no surgimento dos shopping centers. Estes estabelecem um novo padrão funcional e espacial, apropriando o local para o fomento e criação de novas formas de consumo.

De acordo com Silva (2001), a produção do espaço urbano contemporâneo se dá de forma cada vez mais fragmentada. $\mathrm{O}$ crescimento urbano acelerado é guiado pelos interesses de classes sociais e agentes produtores da cidade, que imprimem no espaço uma diferenciação de acordo com os níveis de renda e capacidade de consumo. A cidade com um único núcleo centralizador é passado, abrindo espaço para uma sobreposição de atividades e usos do solo urbano que, nas palavras de Lefèbvre (1999), constituem a cidade polimultinucleada. Os interesses envolvidos na produção do espaço urbano são marcados pelo valor de troca deste espaço, ou seja, o espaço enquanto mercadoria. As cidades estão sujeitas aos processos de reprodução e acumulação do capital.

A complexidade urbana e econômica atual, de acordo com Corrêa (1996), é resultado de uma série de processos espaciais, como centralização, segregação, descentralização e verticalização. Separadas ou atuando em conjunto, estas forças têm a capacidade de reproduzir diversas atividades no espaço, dinamizando suas localizações e consolidando seus fluxos. Segundo Whitacker (2003), a segmentação e fragmentação dos espaços urbanos atuais se dão em diversas escalas. O processo de mundialização da acumulação capitalista e seus mecanismos de comércio de mercadorias e informações possuem papel de destaque:

A fragmentação decorre não de uma tendência de se homogeneizar hábitos de consumo, por exemplo, mas das próprias contradições inerentes ao sistema de produção. Se por um lado, temos a "globalização" de mercados, por outro, temos a diferenciação cada vez maior entre as regiões que abrigam o desenvolvimento da técnica e das decisões, em detrimento daquelas que implementam as técnicas ou que só as "consomem" (WHITACKER, 2003, p. 36).

No interior deste todo complexo, as relações entre as escalas global e local se entrelaçam, com as cidades desempenhando papéis fundamentais quanto à reprodução social dos indivíduos, da realização das trocas comerciais e das decisões quanto aos fluxos financeiros e sua diversificação. Frente a esta realidade, os próprios limites das cidades atuais podem ser questionados, pois a cidade é resultado do processo moderno de urbanização, e este, por sua vez, não é previamente definido, articulando-se às escalas de produção e comercialização mais amplas.

A cidade também é condição para a realização da produção e acumulação capitalista como acontece atualmente, em razão das facilidades proporcionadas pela concentração espacial. Portanto, é primordial para a reprodução ampliada dos processos produtivos, comerciais e sociais.

A cidade organiza o consumo e é suporte e meio de produção, permite as relações e inter-relações necessárias à produção, ao mesmo tempo que, pela conjunção, abarca a essência das relações sociais, das diferenças e dos conflitos (WHITACKER, 2003, p. 61).

Portanto, assiste-se a um incentivo dos espaços de trocas comerciais nas cidades, sendo as relações socioespaciais urbanas (re)criadas pela reprodução do capital agora orientado pelas necessidades e tendências de consumo.

Com as transformações econômicas, sociais, culturais e de transportes no meio urbano, percebe-se uma diminuição relativa do peso comercial do centro principal das cidades, como única centralidade existente. A malha urbana se espalha para novas áreas e pode formar conurbações, como é o caso de Londrina, Ibiporã e Cambé. Surgem subcentros e novas centralidades comerciais, aonde se destacam as lojas de bairro ou de vizinhança. Muitas vezes, a dinâmica comercial periférica e de bairros está relacionada com a descentralização espacial dos estabelecimentos comerciais varejistas e de autosserviço, que modifica hábitos e necessidades de consumo da população que os frequenta.

Evidente que os comerciantes, a partir de suas possibilidades e limitações, escolherão estratégias diferenciadas para suas atividades no meio urbano, estratégias estas que também podem ser consideradas do ponto de vista espacial. No entanto, muitas das necessidades de consumo atualmente estão se igualando, e diferentes tamanhos de loja, com distintos poderes de investimento e localização procuram se adequar às tendências tanto de processos globais quanto dos mercados locais. Isto resulta em centralidades simultâneas e dispersas no espaço urbano, com características marcantes de acordo com seu poder de atração e estabelecimentos comerciais que as constituem.

A partir de um enfoque dialético, a cidade adquire uma essência de relações/articulações de e entre estabelecimentos comerciais presentes em diferentes localizações, que influenciam todo o conjunto 
urbano a cada modificação. Todo este cenário pode ser considerado como de reestruturações urbanas e econômicas e possui uma determinada forma e alcance, a depender do recorte urbano analisado.

Entende-se que as relações espaciais e históricas entre as cidades, os estabelecimentos comerciais e as atividades econômicas varejistas são complexas e ricas em detalhes, fundamentais para a compreensão da dinâmica socioespacial urbana independentemente do período e local analisado. É um cenário instigante para o estudo de elementos próprios da Ciência Geográfica.

\section{O AGLOMERADO URBANO DE LONDRINA}

Com a Lei Estadual Complementar №. 81 - 17/06/98, acrescida pela Lei Estadual Complementar №. 91 05/06/2002, instituiu-se a Região Metropolitana de Londrina - RML (SILVA, 2006). Atualmente, tal região metropolitana se constitui de 25 municípios, com poucos fazendo parte da conurbação. Neste trabalho, chama-se o recorte espacial analisado de aglomerado urbano de Londrina, perfazendo os cinco municípios principais do estudo (Figura 1): Arapongas, Cambé, Ibiporã, Londrina e Rolândia.

Figura 1 - Localização da Região Metropolitana e do aglomerado urbano de Londrina.

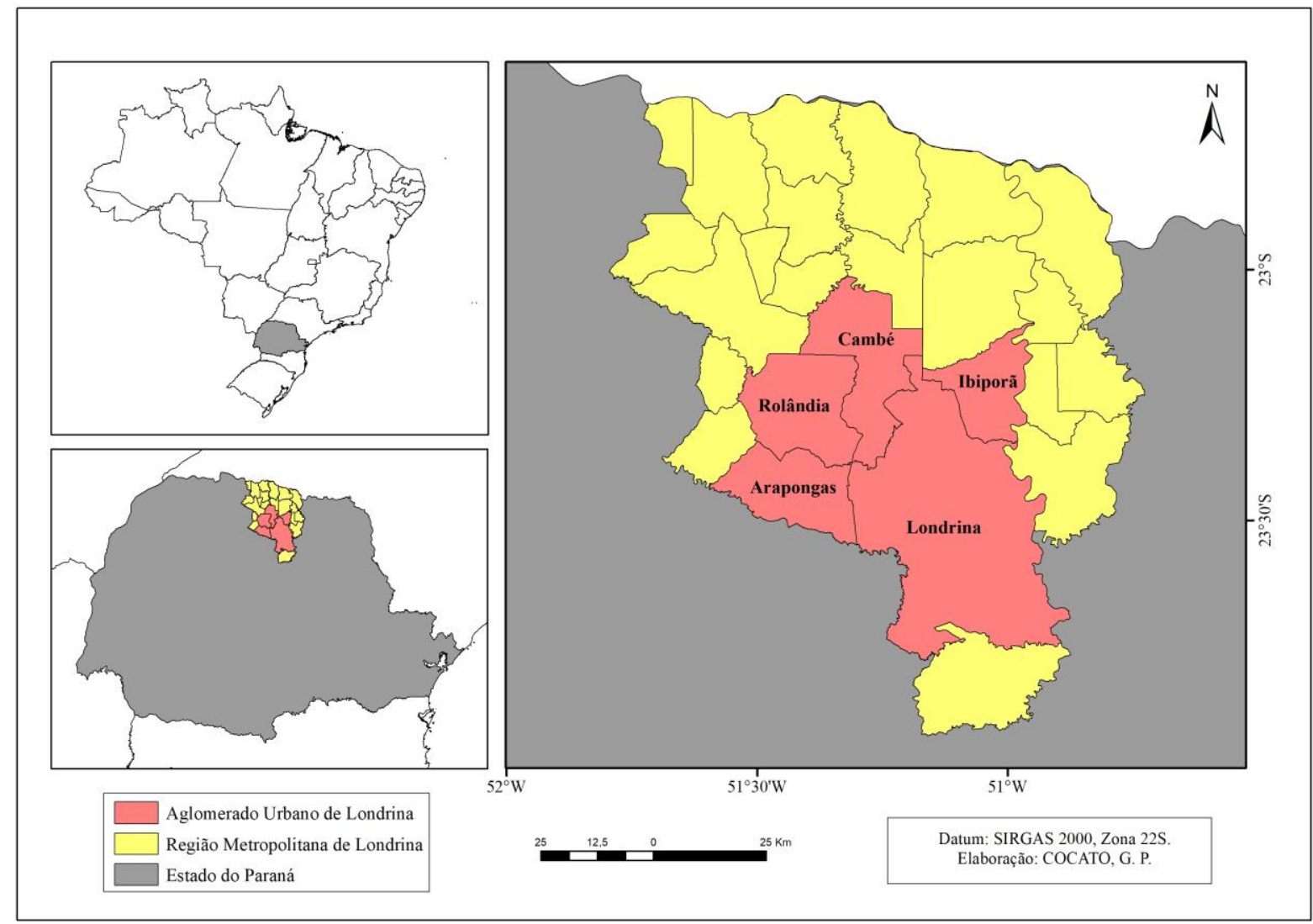

Fonte: BRASIL (2019) e LONDRINA (2019).

A RML foi a primeira do interior paranaense, instituída pela Lei Complementar (LC) ㄲo. 81, em 17 de junho de 1998 (PARANÁ, 1998), fazendo parte de sua composição inicial os municípios de Londrina, Cambé, Ibiporã, Jataizinho, Rolândia e Tamarana. Foi alterada pelas leis ㄲo. . 86, de 07/07/2000 (PARANÁ, 2000) e no. 91, de 05/06/2002 (PARANÁ, 2002), que incluíram os municípios de Bela Vista do Paraíso e Sertanópolis. Em 14/07/2010, através da LC no. 129 (PARANÁ, 2010), foram inclusos Primeiro de Maio, Alvorada do Sul e Assaí. Em 2012 e 2013 houve novas inclusões. Em 2012 foram cinco cidades: Jaguapitã, Pitangueiras e Sabáudia (PARANÁ, 2012a); e Florestópolis e Porecatu (PARANÁ, 2012b). Em 2013, outras nove cidades passaram a fazer parte da RML (PARANÁ, 2013a; 2013b), num total de 25 municípios.

Atualmente, a noção de aglomerações urbanas é marcada por estruturas urbanas mais complexas, com influências que ultrapassam seus limites físicos e administrativos. Sem limites nítidos, geralmente 
acompanham os eixos viários ("tentacularmente") e são acompanhadas/incentivadas pelo estabelecimento de diversas atividades comerciais, que atuam em simbiose com a sociedade de mercado (MOURA, 2013).

Ressalta-se que, neste estudo, considera-se que a região de influência de Londrina não pode ser considerada como região metropolitana somente pela sua institucionalização de cunho e interesses políticos. Deve-se considerar a extensão de sua malha urbana, o tamanho demográfico, as funcionalidades presentes, o grau de integração de suas atividades socioeconômicas, as relações entre hierarquias da rede urbana, o grau de poder econômico-político exercido nas escalas regional, nacional e internacional, entre outros elementos.

No entanto, o tratamento metodológico de Londrina como cidade média apresenta-se de certa forma insuficiente perante a complexidade e fragmentação deste espaço urbano, tanto de maneira singular, como em associação com os municípios de seu entorno. Por isso, optou-se pela nomenclatura do recorte espacial analisado como aglomeração urbana de Londrina, abrangendo o núcleo de habitação mais intensa da região, além da presença marcante de funcionalidades e atividades socioeconômicas pertinentes para este trabalho.

Pode ser o caso de tratar Londrina e seu principal aglomerado como uma nova forma de metropolização, para além da delimitação de cidades médias. No entanto, o debate exige mais detalhamento e dedicação aos fatores que podem influenciar nesta caracterização. Fresca (2013) apresenta considerações pertinentes no sentido de tratar Londrina como um espaço metropolitano com características econômicas semelhantes às metrópoles brasileiras já consolidadas; principalmente no que refere a descentralização de atividades terciárias e no crescimento do mercado imobiliário/construção civil. A expansão e complexificação de centralidades comerciais já está presente em seu estudo.

Considerando as questões apresentadas, ao adotar a terminologia de aglomerado urbano acredita-se não superestimar por motivações políticas a real dimensão da cidade principal e de sua conurbação ainda em crescimento; da mesma maneira em que não são subestimadas as atividades e funcionalidades socioeconômicas presentes em escala intra e interurbana. Atividades estas tanto numerosas, quanto diversas em suas localizações e abastecimento de necessidades e desejos de um crescente número de consumidores.

\section{HISTÓRICO E ATIVIDADES ECONÔMICAS}

Analisando o desenvolvimento histórico de Londrina a partir das atividades comerciais, Grassiotto e Grassiotto (2003) destacam a importância dessas atividades no modo de vida urbano, na dinâmica e possível vocação comercial da cidade. São diversas as maneiras de se compreender as formas e usos do espaço urbano, sendo uma delas a relevância das atividades comerciais e sua relação com processos socioespaciais de um núcleo urbano. A correspondência do objeto de estudo no plano concreto é evidente, assim como as diferentes maneiras de interpretá-lo.

O nascimento histórico das atividades comerciais em Londrina e seu aglomerado estão intimamente ligados a própria fundação da cidade principal, ocorrida em um período que Santos (1996) e Oliveira (2011) chamam de passagem da urbanização pretérita para uma nova urbanização; que marca o contexto brasileiro com a expansão do meio técnico-científico que comanda a passagem do "território arquipélago" agroexportador para a economia urbano-industrial.

Esta nova urbanização acontece em conjunto com a integração material do espaço nacional (avanço das comunicações e transportes) e da expansão da economia de mercado, cada vez mais orientada pela lógica internacional. A rede urbana brasileira se constituiu por meio do comando industrial paulista, mas com o fortalecimento de diversas especializações econômicas regionais, dispersas pelo território (OLIVEIRA, 2011). É com a chamada Revolução de 1930 que a valorização do café paulista encontra sérias barreiras, com a ascensão da economia urbano-industrial, o crescimento das cidades e a aceleração no volume de trabalhadores assalariados.

Assim, a cafeicultura norte-paranaense encontra brechas para se desenvolver, primeiro no Norte Pioneiro. Este desenvolvimento foi conectado diretamente à origem dos primeiros estabelecimentos comerciais urbanos em Londrina (OLIVEIRA, 2011). Esta cidade nasce na década de 1930 por meio de grande empreendimento imobiliário, e é a partir da década de 1940 que o comércio mundial de café retoma gradualmente o seu ritmo.

Construída a partir de 1929, Londrina foi impulsionada por um empreendimento imobiliário movido a capitais ingleses. Tornou-se um município em 1934, distante 380 km de Curitiba e 560 km de São Paulo. Grande parte da região Norte do Paraná foi modernizada com a colonização dirigida, envolvendo capitais

$\begin{array}{lllll}\text { Caminhos de Geografia } \quad \text { Uberlândia-MG } & \text { v. 21, n. } 75 \quad \text { Jun/2020 } & \text { p. 34-51 Página } 39\end{array}$


nacionais e internacionais. Tanto a localização das cidades, quanto o desenvolvimento de suas economias tem forte influência dessas iniciativas concretizadas pela Companhia de Terras.

Alguns fatores foram decisivos no processo de colonização moderna que possibilitou o surgimento e crescimento acelerado destas cidades, principalmente de Londrina: a comercialização de pequenas propriedades, a localização dos núcleos urbanos e a rede viária que, mesmo de forma precária, formavam elos de ligação entre os assentamentos, os núcleos urbanos e as principais rodovias e ferrovias; além de promoverem um esboço de articulação regional com outras cidades e os portos de Santos e Paranaguá (OLIVEIRA, 2011). O conjunto de cidades impulsionado pelo empreendimento imobiliário, em um primeiro momento, foram Londrina, Maringá, Cianorte e Umuarama.

Por Londrina se encontrar em uma localização vantajosa no momento de construção dessas cidades, tornou-se um ponto de conexão entre as escalas local, nacional e internacional de divisão do trabalho e desenvolvimento socioeconômico. Assume então o posto de mais importante e dinâmico centro urbano de toda região (OLIVEIRA, 2011).

A expansão urbana se deu a partir da Avenida Paraná, continuação da via que vinha de lbiporã e ia para Cambé. As primeiras vilas (bairros) mais afastados do centro ocorreram de forma desordenada, principalmente para populações mais pobres. A estrada de ferro estabeleceu uma barreira, ficando as classes populares ao norte e as de maior poder econômico ao sul, área com topografia mais suave e próxima do núcleo urbano. As áreas funcionais - residenciais, comerciais, industriais e de serviços - vão aos poucos ganhando forma. A primeira zona comercial londrinense se constitui a partir de 1935 entre a estrada de ferro e a Avenida Paraná. Também é local de residência, o que demonstra a proximidade entre os estabelecimentos comerciais e os consumidores.

A segunda zona comercial de Londrina surge próxima da praça Willie Davis, na Avenida Paraná, para além da rua Sergipe. Nesse momento, essa localização caracterizava uma concentração de estabelecimentos comerciais mais finos, de atividades diversificadas. Apesar do uso misto entre residências, lojas comerciais e algumas indústrias, forma-se o principal centro da cidade marcado pelas atividades comerciais.

Com a solidez nos preços internacionais do café, após a década de 1940, a industrialização e urbanização nacional se desenvolveram significativamente. $O$ baixo grau de tecnificação nas pequenas propriedades rurais do município auxiliaram na densidade de relações mercantis para a comercialização da produção cafeeira, com o surgimento de numerosos intermediários para venda (em escala nacional e internacional), que se estabeleceram na cidade.

Na década de 1960, de acordo com Oliveira (2011), a cidade havia se tornado um importante centro de decisões comerciais agrícolas e bancárias, exigindo o crescimento do setor de serviços e comércio. $O$ ramo varejista de Londrina possuía armazéns de secos e molhados, com grande variedade de produtos, filiais de empresas nacionais e internacionais, estabelecimentos locais com boa organização etc. O fluxo de visitantes era intenso, e as atividades terciárias se multiplicaram para atender o nível de exigência requerido em um centro urbano que funcionava como polo de atração econômico.

\begin{abstract}
A intermediação na distribuição de bens e serviços exercida por Londrina, em relação ao conjunto de cidades da região, deixa evidente a centralização dos fluxos econômicos na cidade (NAKAGAWARA, 1972). Tal centralização e as necessidades de consumo de um número crescente de comerciantes, profissionais liberais, funcionários públicos, funcionários mais graduados da Companhia de Terras sustentavam a sofisticação do terciário instalado na cidade (OLIVEIRA, 2011, p. 63).
\end{abstract}

Diversos outros tipos de estabelecimentos comerciais também se proliferaram na cidade, atendendo as classes sociais separadas pelos diferentes níveis de renda. O surgimento das primeiras vilas (Nova, Casoni) e favelas ao longo da década de 1950 possibilitaram a dispersão espacial de pequenos estabelecimentos em diferentes pontos da cidade.

Resumidamente, a concentração de riqueza pela atividade agrícola da cafeicultura, em Londrina, acelerou o processo de urbanização e de criação/fortalecimento da atividade comercial varejista na cidade, contribuindo também para o acúmulo de pobreza em alguns espaços. A partir dos anos 1950, a população urbana superou a rural, acelerando-se desde então.

Ao longo dos anos 1970, novas rodovias são construídas no Sul e Sudeste do país, assim como aeroportos, usinas, redes telefônicas e avanço da industrialização. O chamado Projeto Paranaense de Desenvolvimento entra em ação, com forças do Estado promovendo diversas modernizações infraestruturais e nas atividades socioeconômicas existentes. A criação da Companhia Paranaense de 
Energia Elétrica (COPEL) em 1954; da Companhia de Telecomunicações do Paraná (TELEPAR) em 1963 e da Companhia Municipal de Telecomunicações de Londrina (SERCOMTEL) em 1964; e da Companhia de Saneamento do Paraná (SANEPAR) com o sistema de abastecimento Tibagi; possibilitaram avanços importantes nas esferas de energia elétrica, telecomunicações, saneamento básico e rede rodoviária para Londrina e região.

A produção agrícola também se modificou, com a especialização para culturas como a soja, trigo e milho, concomitantemente ao estabelecimento das agroindústrias e cooperativas, que cada vez mais se subordinam ao espaço urbano (OLIVEIRA, 2011). A mudança da cafeicultura para lavouras temporárias mecanizadas também proporcionou um aumento no êxodo rural, transformando trabalhadores rurais em possíveis assalariados urbanos. Portanto, "A concentração do capital, de fato, precedeu a concentração da população" (OLIVEIRA, 2011, p. 95). Este autor destaca que, com as devidas proporções, este mesmo movimento de migração campo-cidade ocorreu nas cidades do entorno de Londrina.

O aumento da população urbana significou mais mão de obra para a economia urbana, estratificada de acordo com os potenciais de consumo pela renda disponível. Neste contexto de diferenciação socioeconômica urbana, a expansão do meio construído ganha destaque, materializando no espaço as desigualdades econômicas e a própria complexidade crescente da economia urbana (OLIVEIRA, 2011). Em relação a expansão da zona Norte londrinense, um fator que influenciou de maneira decisiva o desenvolvimento da região foi a política habitacional dos anos 1970, com recursos federais que financiaram aproximadamente 32 conjuntos habitacionais. Este foi um vetor de crescimento periférico na cidade, com predomínio de moradias populares.

Toda esta complexidade dos espaços urbanos com fortes centralidades intra e interurbanas, a partir da formação de aglomerações (como é o caso de Arapongas, Rolândia, Cambé, Londrina e Ibiporã), intensificam o consumo e promovem incentivos para a disseminação de variados modelos de estabelecimentos comerciais. Consolidada, a chamada sociedade de consumo impõe comportamentos na aquisição de novas mercadorias e serviços:

O tema do consumo remete, via de regra, às discussões sobre a formação da sociedade de consumo de massa nos países do Primeiro Mundo como um dos pontos nevrálgicos da reestruturação capitalista após a grande crise de 1929. Em seus aspectos básicos, a constituição das sociedades de consumo é parte do advento do Capitalismo Monopolista. Também a urbanização intensiva tem papel decisivo nesse processo (OLIVEIRA, 2011, p. 116)

Muitas empresas de consumo cotidiano se instalam na cidade após a década de 1970. É o caso das Casas Buri, Lojas Americanas, Hermes Macedo, Riachuelo, Lojas Arapuã, Armarinhos Paulista, Casas Fuganti, Viscardi e Pernambucanas (essas últimas três já mais antigas). Segundo Oliveira (2011), o shopping Com Tour se junta a estas lojas, representando uma tendência espacial de concentrar atividades comerciais e de serviços; mesma atração exercida pelos super e hipermercados. Entre 1974 e 1993, o número de supermercados em Londrina cresceu $300 \%$, com o surgimento de alguns hipermercados da rede Muffato e Condor (OLIVEIRA, 2011). Uma unidade da rede internacional Carrefour é inaugurada em conjunto com o shopping Catuaí, no início dos anos 1990.

Complexificam-se então os tipos de estabelecimentos comerciais, para atendimento diferenciado de cada parcela de uma sociedade estratificada. Em conjunto, o desenvolvimento do meio construído possibilita que tais atividades se consolidem; assim como a economia urbana como todo, em sua unidade e fragmentação. As atividades comerciais se dispersam pela cidade, ocupando outros espaços além do centro principal. Centralidades são produzidas, fazendo parte do processo de reestruturação urbana.

Resumindo o desenvolvimento das atividades comerciais em Londrina, Grassiotto e Grassiotto (2003) descrevem que estas se estabeleceram primeiramente no centro principal da cidade, para depois se descentralizar em subcentros/centralidades espontâneas (ruas Araguaia, Maringá e Saul Elkind e avenidas Bandeirantes, Inglaterra e Arthur Thomas). O terceiro momento é marcado pelo aparecimento dos shopping centers como novas centralidades dispersas (em áreas centrais e periféricas), primeiro com o Com Tour (1973) e depois com o Catuaí (1990) e Royal Plaza (1999).

Entende-se que Londrina exerce uma centralidade considerável na Região Norte do Paraná, justamente por atrair consumidores em um amplo raio espacial. Neste contexto, destaca-se a importância dos

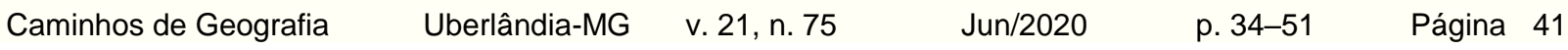


estabelecimentos comerciais varejistas neste aglomerado urbano. Tratando-se de toda atividade varejista - de grande ou pequeno porte e dos mais diversos tipos - as estratégias espaciais (possibilidades de localização) são imprescindíveis; tendo as empresas de maior capital e poder financeiro as maiores capacidades de escolha.

Como exemplos da força de concentração socioeconômica dos cinco municípios do aglomerado urbano de Londrina, têm-se alguns dados que corroboram a intensidade dos fluxos entre eles, e a potencialidade de suas atividades que se estendem por distâncias cada vez maiores, tanto em âmbito regional, quanto estadual.

Em 2013, simbolizando as atividades relacionadas ao transporte, a frota de veículos dos cinco municípios do aglomerado totalizava 526.771, correspondendo a $84,5 \%$ dos veículos existentes na Região Metropolitana de Londrina (RML) como todo. Em 2017, de acordo com a Prefeitura do Município de Londrina (LONDRINA, 2018) somente Londrina possuía 375.179 unidades.

O movimento no terminal rodoviário de Londrina foi significativo em 2017, com 2.390 .810 passageiros em 111.432 chegadas e partidas de veículos do local. Já os passageiros do transporte aéreo, provenientes do aeroporto José Richa em Londrina, somaram 880.023 em 2017 (LONDRINA, 2018).

A população economicamente ativa destes municípios, em 2010, totalizava 443.759 pessoas, representando $82,4 \%$ deste grupo presente em toda a RML (LONDRINA, 2014). Já a arrecadação de Imposto sobre Circulação de Mercadorias e Serviços (ICMS), no âmbito das atividades comerciais, em 2013 , totalizou $\mathrm{R} \$ 411.978 .156,73$, sendo $69,3 \%$ dos valores de ICMS do comércio arrecadados em toda RML e $27,8 \%$ de todo o ICMS arrecadado com todas as atividades taxadas nos cinco municípios do recorte espacial analisado (LONDRINA, 2014).

Neste âmbito, qual seria a representatividade do varejo? Especificando a análise, a atividade varejista, em 2017, apresentou 2.083 estabelecimentos na divisão 45 (Comércio e Reparação de Veículos Automotores e Motocicletas) e 10.185 na divisão 47 (Comércio Varejista), ambas definições da Classificação Nacional de Atividades Econômicas - CNAE 2.0 (LONDRINA, 2018). De acordo com este mesmo documento, o comércio varejista, dentro dos diversos setores econômicos existentes em Londrina, representou 17.528 admissões em empregos formais para o ano de 2017. Paradoxalmente, houve 17.341 desligamentos de vínculos empregatícios no mesmo setor, indicando o alto grau de rotatividade dos postos de trabalho nesta atividade comercial.

Considerando o ramo comercial, estavam presentes nos cinco municípios do aglomerado urbano de Londrina: 8.167 estabelecimentos comerciais e 46.598 vínculos empregatícios ativos ao final do ano. Isto representa $30,5 \%$ de todos os estabelecimentos do aglomerado urbano presentes na Relação Anual de Informações Sociais - RAIS (BRASIL, 2017b), e 18,4\% de todos os vínculos empregatícios da mesma base de dados.

Em uma série histórica (Figura 2), iniciando em 2010, percebe-se uma manutenção nos números de estabelecimentos e de empregos gerados pelo ramo de comércio varejista nos cinco municípios selecionados. 
Figura 2 - Evolução dos estabelecimentos e vínculos empregatícios do comércio varejista no aglomerado urbano de Londrina (2010-2017).

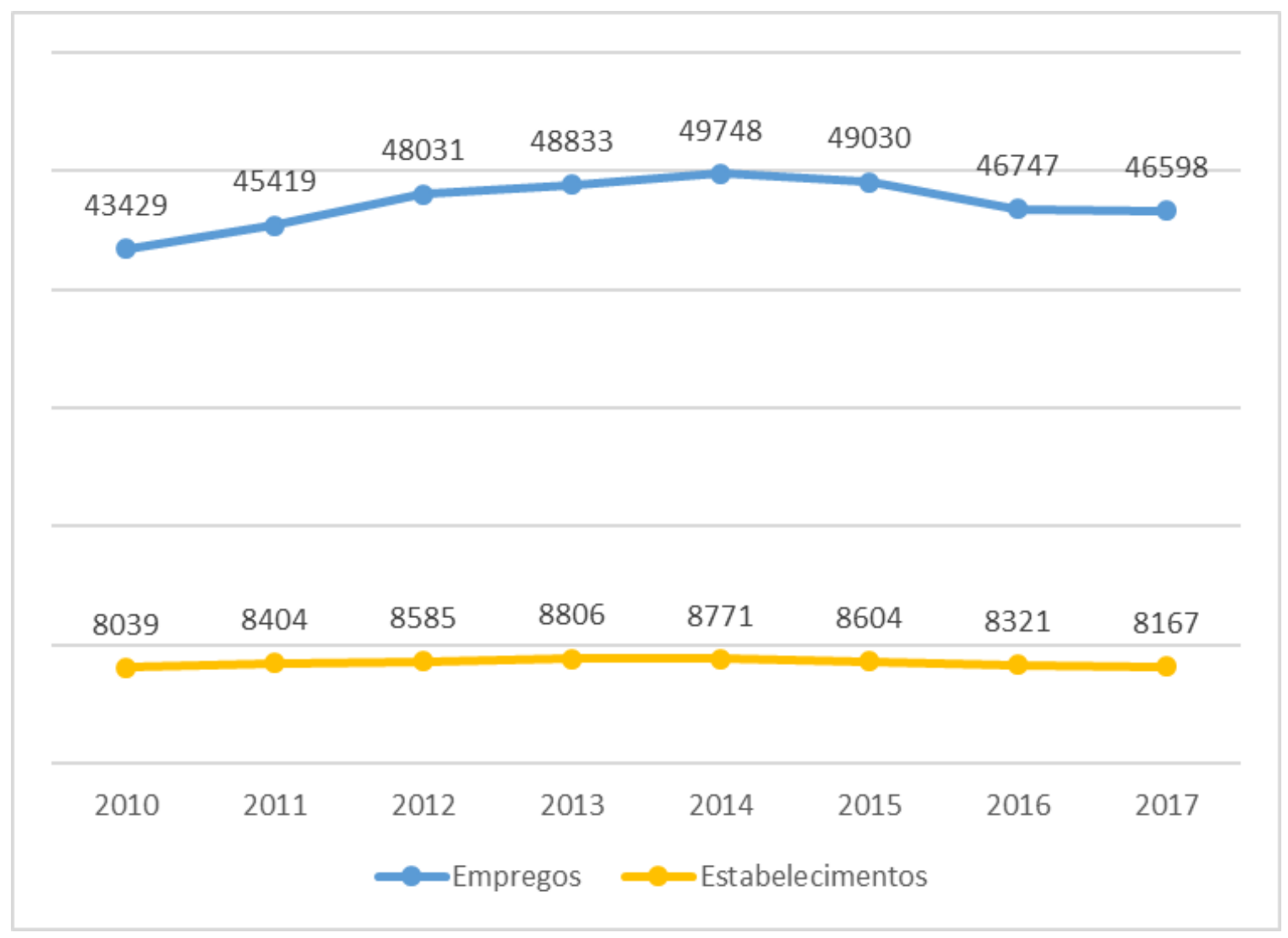

Fonte: BRASIL (2017b). Org.: autor.

De forma a demonstrar a presença contínua dos estabelecimentos varejistas do aglomerado urbano de Londrina, foi realizada uma seleção de dados a partir do Cadastro Nacional de Endereços para Fins Estatísticos - CNEFE (BRASIL, 2010). Nesse processo, foram eliminados todos os estabelecimentos que não se adequassem à definição varejista da Classificação Nacional de Atividades Econômicas - CNAE (BRASIL, 2017a).

Citando Porto-Sales et al. (2014), o CNEFE pode ser considerado uma ferramenta importante em análises geográficas. Com a necessidade de se obter um banco de dados confiável acerca de atividades e uso do solo urbano, sem possuir os recursos para tão colossal levantamento de campo, o CNEFE é um instrumento extremamente relevante para a análise e filtragem de dados espaciais. Existem ressalvas, pois como Porto-Sales et al. (2014) afirma, o CNEFE não foi produzido com o intuito de ser uma base de dados de atividades econômicas, então para o estudo de tais variáveis existem dificuldades inerentes à sua classificação. Deve-se, portanto, padronizar a ação de distinguir os estabelecimentos, evitando duplicações e traduzindo denominações diversas e expressões genéricas.

Apesar de serem dados referentes ao Censo Nacional Demográfico, portanto de 2010, estes ilustram a espacialização abrangente do varejo nos municípios estudados (Figura 3). 
Figura 3 - Setores censitários com presença de estabelecimentos varejistas no aglomerado de Londrina (2010).

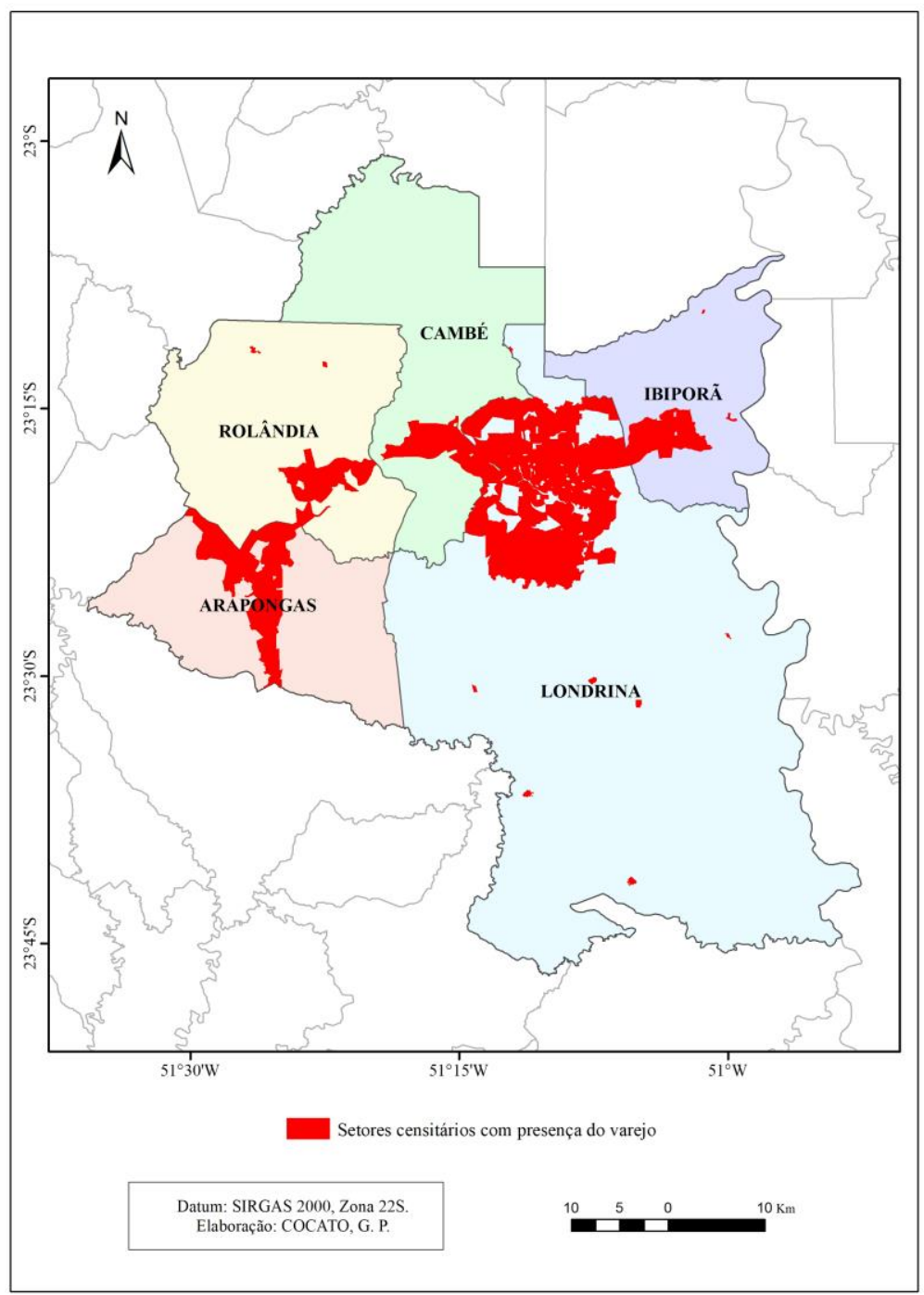

Fonte: BRASIL (2010; 2019) e LONDRINA (2019).

Pela Figura 3, percebe-se que grande parte dos setores censitários urbanos do aglomerado possuem a presença de estabelecimentos varejistas, o que reforça os fluxos consumidores entre eles, fomentado a mobilidade de pessoas e mercadorias intra e interurbana. Esta espacialização pulverizada alimenta a formação de centralidades em diversos pontos do conjunto urbano, propiciando a satisfação de necessidades básicas de consumo para populações centrais e periféricas, a partir de diferentes níveis de atração comercial.

Principalmente em Londrina, para além do grande número de estabelecimentos varejistas, muitos destes comercializam uma ampla gama de mercadorias. A partir de observações cotidianas, entende-se que esses estabelecimentos comerciais estão presentes em toda a malha urbana estudada, concentrados e, simultaneamente, dispersos. Mas, para que seja possível realizar tal afirmação, é necessário confirmar essa realidade empiricamente.

\section{DOS PEQUENOS VAREJOS ÀS MULTICENTRALIDADES}

Neste ponto, para enriquecer as análises realizadas em âmbito teórico/metodológico, realizaram-se alguns trabalhos de campo para a observação, detalhamento e descrição destas centralidades/dispersões varejistas. Esta etapa é fundamental para a compreensão de como os varejos se estabelecem no aglomerado urbano de Londrina. 
Para a realização dos trabalhos de campo, feitos durante quatro sábados em abril de 2019, foram escolhidos 18 setores censitários do aglomerado urbano de Londrina, sendo 10 em Londrina (dois para cada subdistrito urbano: Norte, Sul, Leste, Oeste e Centro) e oito em Arapongas, Cambé, Ibiporã e Rolândia (dois para cada). Essa escolha de visitas in loco em pares de setores censitários por subdistrito urbano/município se deu pelo fato de abranger possíveis disparidades entre setores do mesmo município.

De acordo com a Figura 4, percebe-se a distribuição espacial dos locais/setores escolhidos:

Figura 4 - Localizações dos setores censitários para trabalhos de campo.

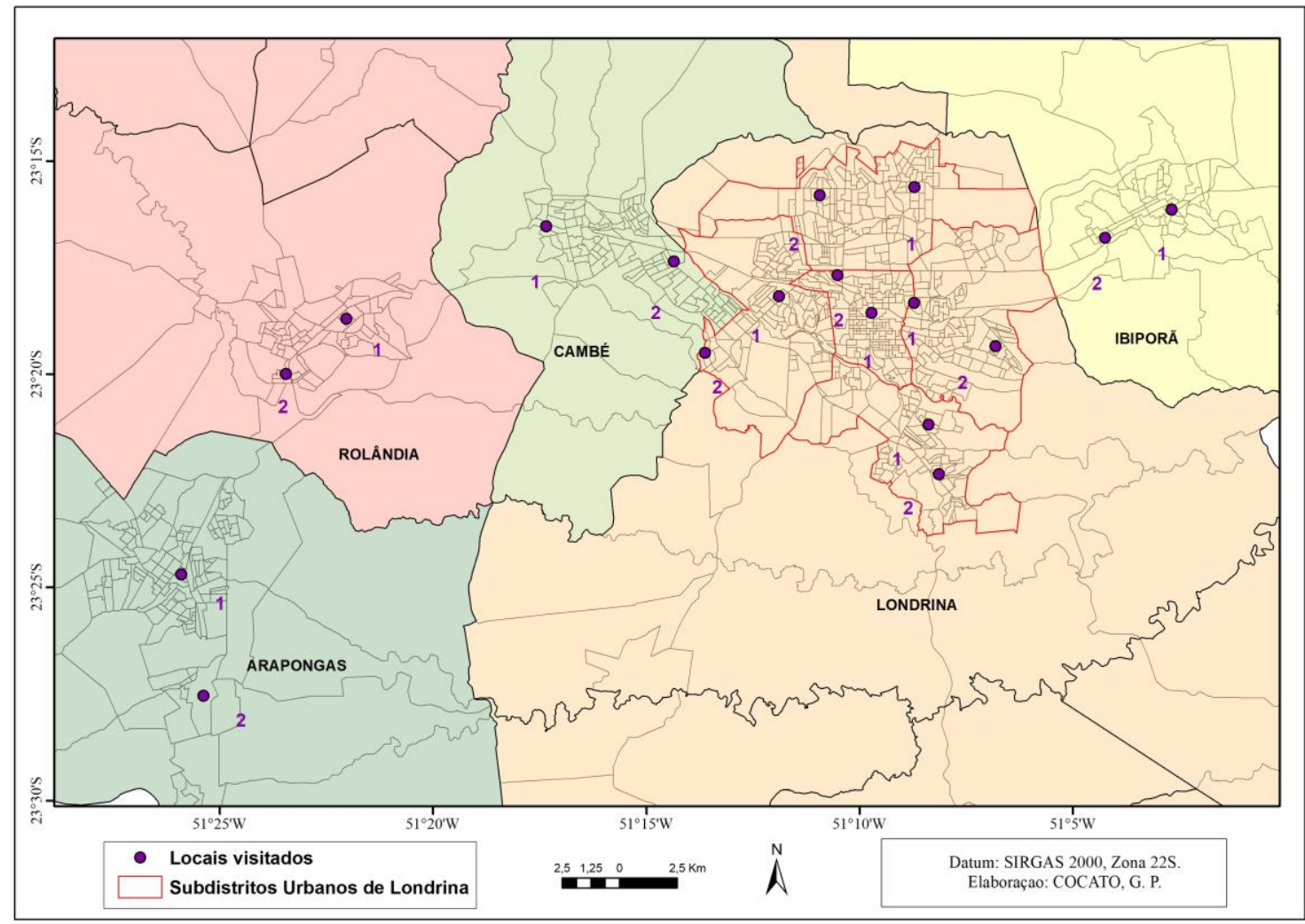

Fonte: BRASIL (2010; 2019) e LONDRINA (2019).

Durante os trabalhos de campo, aferiu-se que as empresas varejistas estão presentes em grande número de bairros que compõem a malha urbana. Comerciantes de mercadorias novas e usadas, sejam elas calçados, vestuários, alimentos, eletrodomésticos, veículos, produtos farmacêuticos entre outros, são exemplos da diversidade e versatilidade dos estabelecimentos do comércio varejista disperso ao longo do espaço urbano.

Foram observados que são os pequenos estabelecimentos comerciais que se estabelecem em espaços periféricos/dispersos e descentralizados, enfrentando dificuldades com recursos financeiros escassos. Algumas dessas localidades possuem um aglomerado maior de estabelecimentos, com uma frequência também maior de consumidores. De forma geral, os varejos estão presentes em todos os pontos periféricos visitados.

As micro e pequenas empresas são fundamentais nesse contexto, principalmente em relação aos empregos e renda gerados (inclusive no recente cenário de crise financeira e estagnação econômica) e no dinamismo para a estrutura produtiva voltada ao mercado interno de bens e serviços, pois

[...] absorve os choques dos períodos de baixa e de incerteza na conjuntura econômica, desempenha muitas das tarefas menos compensadoras, porém necessárias, na economia e assimila a queda de resíduos provenientes das atividades de elevado risco. [...] proporcionam, outrossim, os amortecedores no ambiente econômico que protegem a lucratividade e o bem-estar das empresas de grande porte (SOLOMON, 1986, p. 10). 
Podem inclusive ser reconhecidas como instrumentos fundamentais na luta contra a pobreza e a desigualdade socioeconômica e socioespacial, em âmbito nacional e local/regional, tendo as cidades como lócus privilegiado, em razão das condições nelas presentes. Em essência, comercializam produtos variados; com predominância de vestuário (bazares e brechós, principalmente), calçados, acessórios, usados (inclusive móveis) e alguns itens de alimentação presentes em mercearias e padarias.

Possuem poucos funcionários, são, em geral, empresas familiares, e podem tanto procurar melhores localizações em aglomerações comerciais centrais ou de bairros, quanto se adaptar à realidade do ambiente construído em que, geralmente, se situam próximos das residências dos proprietários; quando não compartilham o mesmo imóvel.

Em cada setor censitário visitado foram feitas observações e registradas fotografias sobre os varejos presentes. As Figuras 5, 6, 7 e 8 ilustram alguns dos pequenos estabelecimentos percebidos nos trabalhos de campo, que se dispersam espacialmente pelo aglomerado urbano de Londrina. Este pioneirismo do pequeno varejo pode abrir caminhos para outros estabelecimentos, gradualmente formando simples concentrações que podem tornar-se centralidades urbanas.

Dada a distribuição espacial dos estabelecimentos comerciais varejistas, pertencentes a diferentes grupos de atividades econômicas, entende-se que a diversificação deste ramo no espaço urbano é alta. Apresentam-se de forma concentrada nos centros urbanos principais e em alguns setores específicos do aglomerado; assim como de maneira numerosa e dispersa espacialmente, podendo constituir multicentralidades ao longo do recorte espacial estudado. Além disso, mesmo atividades varejistas que se estabelecem de forma reduzida nos centros, periferias e subdistritos urbanos de Londrina, ainda se destacam por sobreviver nestes espaços - muitas vezes com grande dificuldade financeira e com a presença de concorrência crescente.

Figura 5 - Pequenos estabelecimentos comerciais varejistas (produtos para animais, bicicletas e material de construção) em Arapongas 2.

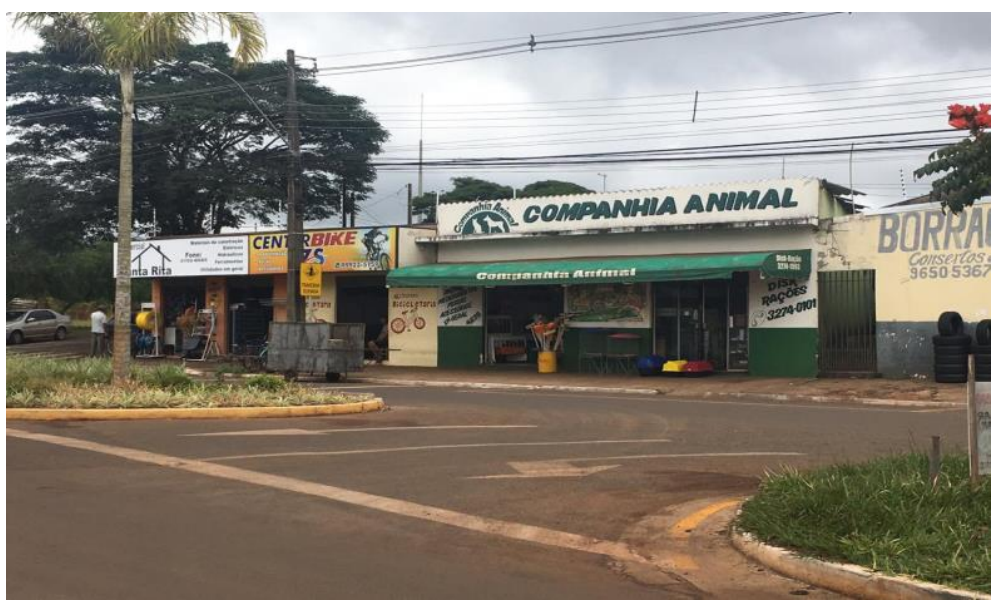

Fonte: o autor.

Figura 6 - Pequenos estabelecimentos comerciais varejistas (farmácia e móveis) em Cambé 2.

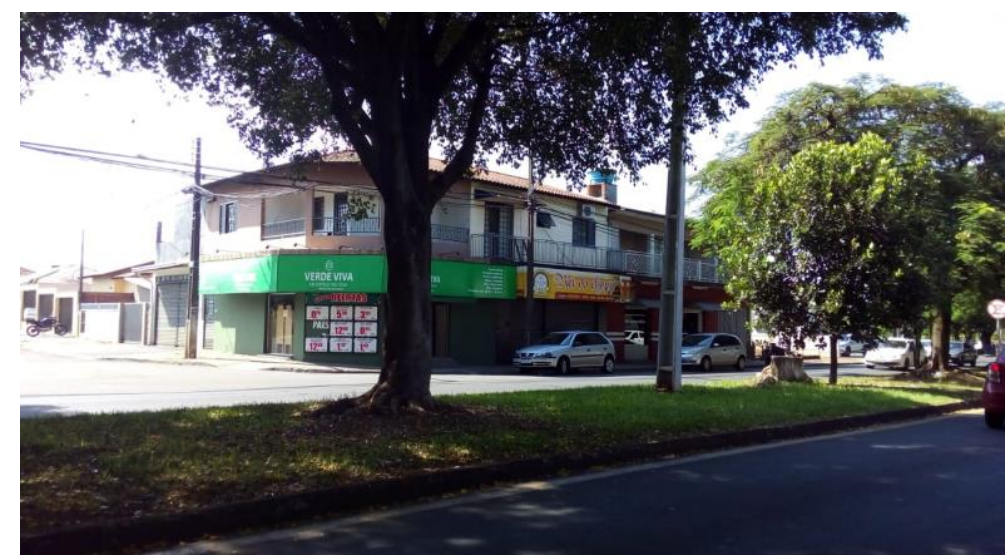

Fonte: o autor. 
Figura 7 - Pequenos estabelecimentos comerciais varejistas (farmácia, padaria e eletrônicos) em lbiporã 2.

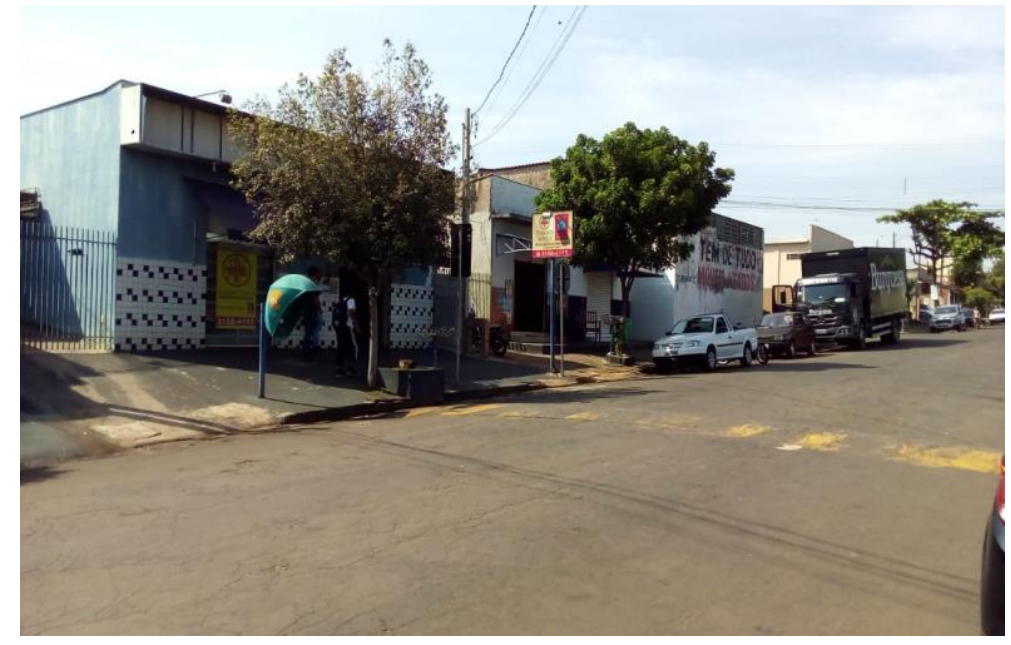

Fonte: o autor.

Figura 8 - Pequenos estabelecimentos comerciais varejistas (açougue, sacolão e móveis usados) em Londrina Leste 2.

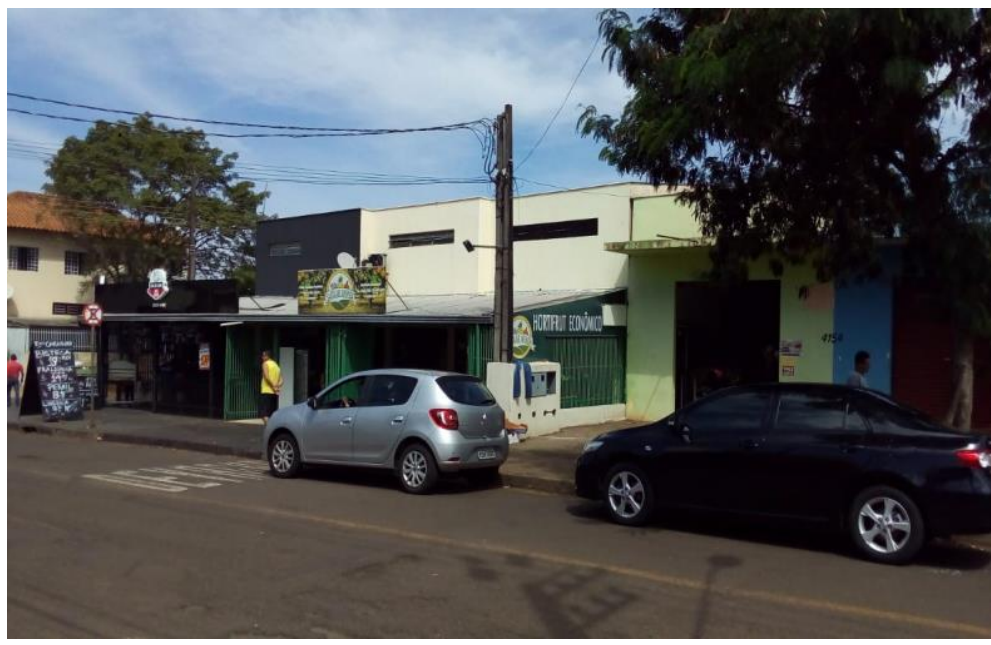

Fonte: o autor.

Nos espaços visitados, o fator ambiente construído é determinante. Melhorias infraestruturais são muito importantes, visando a acessibilidade de pedestres e veículos (estacionamento), mas também para se aproveitar da proximidade com consumidores de bairros periféricos, estabelecendo relações próximas e pessoais, ao mesmo tempo que em que se adaptam em termos de mercadorias e serviços oferecidos. Constituem assim, uma infinidade de possíveis centralidades concentradas e/ou descentralizadas nas cidades do aglomerado urbano de Londrina.

As vias urbanas, com seu potencial de acessibilidade, em conjunto com a presença de estacionamentos, calçadas amplas e arborização bem cultivada são elementos essenciais para suprir o intenso fluxo de veículos existentes nas cidades. Muitos dos principais centros observados se encontravam em estado de saturação de seus acessos, o que pode contribuir para a descentralização varejista.

Em locais onde os varejos se descentralizam, dispersos pelo aglomerado, favorece-se o fluxo de consumidores a pé, além do transporte urbano (se este existir) e dos já citados automóveis. Estabelecemse relações mais próximas entre os estabelecimentos comerciais e os residentes de entorno, e/ou com passantes que utilizam determinadas rotas todos os dias, seja para trabalho ou estudo (migração pendular). O transporte urbano descentralizado, em Londrina, auxilia nos fluxos centrais e periféricos, atendendo não somente as principais centralidades, mas também pequenas concentrações recentes.

Ressalta-se que a descentralização dos estabelecimentos varejistas, dispersos pelo aglomerado urbano de Londrina, abrem oportunidades para outras atividades comerciais e de serviços se concentrarem nas

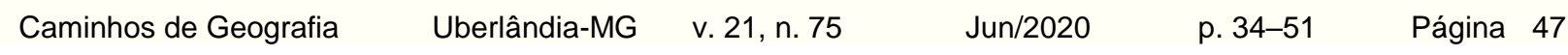


mesmas localidades, em busca de menores custos, maiores vendas e do suprimento das necessidades de populações periféricas. Como percebido pelas análises realizadas até aqui, os pequenos estabelecimentos varejistas são muito atuantes nesse processo. Portanto, a descentralização do pequeno varejo pode induzir à multicentralidade, e esta última reforça a descentralização em relação aos centros tradicionais específicos.

Entende-se que são movimentos socioespaciais contínuos e simultâneos, que se influenciam mutuamente: a descentralização contribui para a dispersão dos estabelecimentos varejistas e para a formação de variadas concentrações que podem se tornar multicentralidades; enquanto a formação destas múltiplas centralidades auxiliam na consolidação destes pontos de atração e abrem novas oportunidades espaciais de localização para as atividades comerciais e de serviços, geralmente periféricas, dispersas, mas aglomeradas (em diferentes níveis de concentração); em um duplo movimento espacial urbano, centrípeto e centrífugo.

É evidente que estas aqui chamadas multicentralidades não serão do mesmo porte que as centralidades principais de cada município, antigas e já bem estabelecidas; e nem que serão semelhantes em termos de funcionalidade com subcentros consolidados. No entanto, podem proporcionar uma dinamicidade única às relações socioeconômicas urbanas, contribuindo para a reprodução social nas cidades enquanto abastecem necessidades básicas e diversificam os produtos disponíveis - para milhares de pessoas residentes em dispersas periferias e extensas/ramificadas malhas urbanas do aglomerado de Londrina.

\section{CONSIDERAÇÕES FINAIS}

A partir deste estudo, confirma-se na realidade a importância de alguns aspectos teóricos discutidos anteriormente. A presença marcante dos estabelecimentos comerciais varejistas reforça a importância desse ramo para o aglomerado urbano de Londrina.

Existem diversas concentrações de estabelecimentos comerciais; grandes, médias e pequenas, dependendo da constituição das centralidades ou periferias observadas. Mesmo em pequenas concentrações varejistas descentralizadas, delimitadas para os trabalhos de campo, aparecem potencialidades para possíveis centralidades, mesmo que com uma força de atração menor em relação aos centros e subcentros já consolidados.

Com a espacialização ampla e pulverizada dos pequenos estabelecimentos varejistas pelo aglomerado, entende-se que outras atividades podem se aproveitar das condições favoráveis de consumo e infraestrutura por eles proporcionada/incentivada e se aglomerarem nos mesmos espaços; formando as multicentralidades.

Pequenas concentrações varejistas são fundamentais para o abastecimento dos residentes nos espaços urbanos estudados e realização das necessidades básicas da população de entorno. Pelo consumo proporcionado, os estabelecimentos comerciais ligados à alimentação, vestuário (pequeno e de peças usadas), itens domésticos e variedades são essenciais à dinâmica urbana contemporânea.

Para o aglomerado urbano de Londrina, considerando a presença numerosa dos varejos, concentrados em alguns locais, mas também dispersos, compreende-se que essa espacialização descentralizada pode representar uma das principais influências para o peso econômico terciário destas cidades, especialmente Londrina. Essa configuração espacial por pequenas concentrações varejistas - confirmada por dados institucionais, discussão teórico-metodológica e observações in loco - para além dos shopping centers e centralidades principais, podem ser encaradas como representações de uma aglomeração urbana brasileira multicentralizada. Neste caso, complexificada pelas relações intra e interurbanas de um conjunto de cidades que se constituem enquanto aglomerado urbano.

\section{REFERÊNCIAS}

BRASIL. Ministério do Planejamento, Orçamento e Gestão. IBGE - Instituto Brasileiro de Geografia e Estatística. Censo Demográfico. Cadastro Nacional de Endereços para Fins Estatísticos (CNEFE). Rio $\begin{array}{lllll}\text { de Janeiro: } & \text { n. } & \text { n.] } & \text { Disponível } & \text { em: }\end{array}$ <https://ww2.ibge.gov.br/home/estatistica/populacao/censo2010/cnefe/default_cnefe.shtm>. Acesso em: 20 ago. 2018.

Mapas. Bases e referenciais. Bases cartográficas. Malhas digitais. Rio de Janeiro: [s. n.], 2019. Disponível em: <https://mapas.ibge.gov.br/bases-e-referenciais/bases-cartograficas/malhas-digitais.html>. Acesso em: 05 mar. 2019.

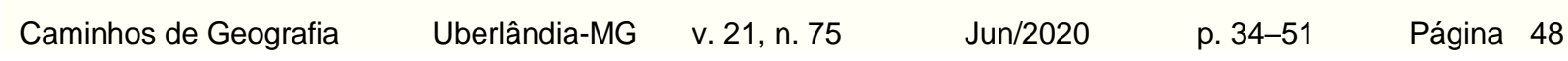


CONCLA - Comissão Nacional de Classificação. Classificação Nacional de Atividades Econômicas (CNAE 2.0). Rio de Janeiro: [s. n.], 2017a. Disponível em: <https://concla.ibge.gov.br/buscaonline-cnae.html?view=estrutura>. Acesso em: 20 ago. 2018.

BRASIL. Ministério do Trabalho. PDET - Programa de Disseminação das Estatísticas do Trabalho. Relação Anual de Informações Sociais (RAIS). Brasília: [s. n.], 2017b. Disponível em: <http://bi.mte.gov.br/bgcaged/login.php>. Acesso em: 04 mar. 2019.

BRAUDEL, F. Civilização material, economia e capitalismo: séculos XV-XVIII - Volume 2 - Os jogos das trocas. Tradução de Telma Costa. São Paulo: Martins Fontes, 1996. Tradução de: Civilisation matérielle, économie et capitalisme - Tome II - Les jeux de l'échange.

CORRÊA, R. L. A rede urbana. São Paulo: Ática, 1996.

FRESCA, T. M. O espaço metropolitano de Londrina - PR: novas centralidades e mercado imobiliário. Revista de Geografia, Recife, v. 30, n. 2, p. 51-78, 2013. Disponível em: <https://periodicos.ufpe.br/revistas/revistageografia/article/view/229020>. Acesso em: 20 jun. 2019.

GIANSANTI, R.; SCARLATO, F. C.; FURLAN, S. A. O desafio do desenvolvimento sustentável. São Paulo: Atual, 2003.

GRASSIOTTO, M. L. F.; GRASSIOTTO, J. de A. A atividade comercial e sua relação com o urbano: o exemplo de Londrina. Semina: Ciências Sociais e Humanas, Londrina, v. 24, n. 1, p. 101-120, set. 2003. Disponível em: <http:/www.uel.br/revistas/uel/index.php/seminasoc/article/view/3840>. Acesso em: 20 dez. 2018. https://doi.org/10.5433/1679-0383.2003v24n1p101

HARVEY, D. Os limites do capital. Tradução de Magda Lopes. São Paulo: Boitempo, 2013. Tradução de: The limits to capital.

LEFÈBVRE, H. A revolução urbana. Belo Horizonte: UFMG, 1999. Tradução de Sérgio Martins.

LONDRINA (Município). Perfil do Município de Londrina. Secretaria Municipal de Planejamento, Orçamento e Tecnologia. Londrina: [s. n.], 2018. Disponível em: <http://www.londrina.pr.gov.br/dados/images/stories/Storage/sec_planejamento/perfil/2018/perfil_2018_atu alizado.pdf>. Acesso em: 03 mar. 2019.

Perfil da Região Metropolitana de Londrina. Secretaria Municipal de Planejamento, Orçamento $\begin{array}{lllll}\text { e Tecnologia. } & \text { Londrina: } & \text { n.], } & 2014 . & \text { Disponível }\end{array}$ <http://www.londrina.pr.gov.br/dados/images/stories/Storage/sec_planejamento/perfil/regiao_metropolitana /perfil_rml_2014.pdf>. Acesso em: 03 mar. 2019.

Disponível

Sistema de Informação Geográfica de Londrina (SIGLON). Downloads. Londrina: [s. n.], 2019.

<http://www.londrina.pr.gov.br/index.php?option=com_content\&view=article\&id=20114\&ltemid=1988>

Acesso em: 05 mar. 2019.

MOURA, R. Configurações espaciais na metropolização brasileira. VI Seminario Internacional Red de Investigación sobre Áreas Metropolitanas de Europa y América Latina (RIDEAL), Medellín, Colombia. E-Metropolis, no 13, ano 4, 2013.

OLIVEIRA, E. L. de. Divisão do trabalho e circuitos da economia urbana. Londrina: EdUEL, 2011.

OLIVEIRA, I. C. E. Estatuto da cidade: para compreender. Rio de Janeiro: IBAM/DUMA, 2001.

PARANÁ (Estado). Casa Civil. Lei Complementar no. 81, de 17 de Junho de 1998. Institui a Região Metropolitana de Londrina, constituída pelos municípios que especifica. Curitiba: Diário Oficial no. 5272 , 1998. Disponível em: <https://www.legislacao.pr.gov.br/legislacao/listarAtosAno.do?action=exibir\&codAto=8483\&indice=1\&total Registros=5\&anoSpan=1999\&anoSelecionado=1998\&mesSelecionado=0\&isPaginado=true $>$. Acesso em: 10 set. 2019.

Lei Complementar no. 86, de 07 de Julho de 2000. Dá nova redação ao art. 1ํ, da Lei Complementar no. 81, de 17 de Junho de 1998. Curitiba: Diário Oficial n‥ 5780, 2000. Disponível em: <https://www.legislacao.pr.gov.br/legislacao/listarAtosAno.do?action=exibir\&codAto=8040\&indice=1\&total Registros=2\&anoSpan=2009\&anoSelecionado=2000\&mesSelecionado=0\&isPaginado=true $>$. Acesso em: 10 set. 2019. 
Lei Complementar no. 91, de 05 de Junho de 2002. Dá nova redação ao art. 1o, da Lei Complementar nํ. 81, de 17 de Junho de 1998. Curitiba: Diário Oficial no. 6244, 2002. Disponível em: $<$ https://www.legislacao.pr.gov.br/legislacao/listarAtosAno.do?action=exibir\&codAto=8020\&indice=1\&total Registros=8\&anoSpan=2009\&anoSelecionado=2002\&mesSelecionado=0\&isPaginado=true $>$. Acesso em: 10 set. 2019.

. Lei Complementar no. 129, de 14 de Julho de 2010. Fica alterado o art. 1ํ, da Lei Complementar no. 81, de 17 de junho de 1998, que foi alterada pelas Leis Complementares n‥ 86/2000 e n‥ 91/2002, que instituiu a Região Metropolitana de Londrina. Curitiba: Diário Oficial n. 8262, 2010. Disponível em: <https://www.legislacao.pr.gov.br/legislacao/listarAtosAno.do?action=exibir\&codAto=56182\&indice=1\&total Registros=10\&anoSpan=2019\&anoSelecionado=2010\&mesSelecionado=0\&isPaginado=true $>$. Acesso em: 10 set. 2019.

Lei Complementar no. 144, de 05 de Abril de 2012. Altera o art. 1ํ da Lei Complementar no. 81/1998, incluindo os Municípios de Sabáudia, Jaguapitã e Pitangueiras na Região Metropolita de Londrina. Curitiba: Diário Oficial no. 8690, 2012a. Disponível em: <https://www.legislacao.pr.gov.br/legislacao/listarAtosAno.do?action=exibir\&codAto=66634\&indice=1\&total Registros $=12$ \&anoSpan=2019\&anoSelecionado=2012\&mesSelecionado=0\&isPaginado=true $>$. Acesso em: 10 set. 2019 .

Lei Complementar no. 147, de 16 de Julho de 2012. Altera o art. 1ํ da Lei Complementar n‥ 81, de 17/06/98, incluindo os Municípios de Florestópolis e Porecatu na Região Metropolitana de Londrina. Curitiba: Diário Oficial $\mathrm{n} \times$. $8755, \quad 2012 \mathrm{~b}$. Disponível em: <https://www.legislacao.pr.gov.br/legislacao/listarAtosAno.do?action=exibir\&codAto=71574\&indice=1\&total Registros=12\&anoSpan=2019\&anoSelecionado=2012\&mesSelecionado=0\&isPaginado=true $>$. Acesso: 10 set. 2019.

Lei Complementar no. 157, de 09 de Julho de 2013. Altera a redação do art. 1ํ da Lei Complementar nํ. 81, de 1998, inserindo o Município de Arapongas entre os que compõem a Região Metropolitana de Londrina. Curitiba: Diário Oficial no. 8995, 2013a. Disponível em: <https://www.legislacao.pr.gov.br/legislacao/listarAtosAno.do?action=exibir\&codAto=99135\&codltemAto=6 53414\#653414>. Acesso em: 10 set. 2019.

Lei Complementar no. 165, de 14 de Novembro de 2013. Altera o art. 1ํ da Lei Complementar nº. 81, de 17 de junho de 1998, incluindo os Municípios de Centenário do Sul, Guaraci, Lupionópolis, Mirasselva, Prado Ferreira e Uraí, Rancho Alegre e Sertaneja na Região Metropolitana de Londrina. Curitiba: Diário Oficial n․ 2013b. 9090, Disponível: <https://www.legislacao.pr.gov.br/legislacao/listarAtosAno.do?action=exibir\&codAto=109356\&codltemAto= 698832\#698832>. Acesso em: 10 set. 2019.

PORTO-SALES, A. L. et al. Pesquisa em Geografia urbana: desafios e possibilidades de análise espacial com o uso do Cadastro Nacional de Endereços para Fins Estatísticos (CNEFE). Caderno Prudentino de Geografia, Presidente Prudente, n. 36, v. 2, p. 81-103, ago./dez. 2014. Disponível em: $<$ http://revista.fct.unesp.br/index.php/cpg/article/view/3194>. Acesso em: 17 ago. 2018.

SANTOS, M. A natureza do espaço: técnica e tempo, razão e emoção. São Paulo: Hucitec, 1996.

Técnica, espaço, tempo - globalização e meio técnico-científico informacional. 2. ed. São Paulo: Hucitec, 1997.

SILVA, C. H. C. da. Estudos sobre o comércio e o consumo na perspectiva da Geografia urbana. Revista Geosul, Florianópolis, v. 29, n. 58, p. 149-178, jul./dez. 2014. Disponível em: <https://periodicos.ufsc.br/index.php/geosul/article/view/26590>. Acesso em: 12 mai. 2018.

SILVA, M. B. da. A dinâmica do comércio de autosserviço do varejo alimentar e a expansão das lojas de vizinhança na cidade de Uberaba (MG). 2011. 140 f. Dissertação (Mestrado em Geografia) Universidade Federal de Uberlândia, Uberlândia, 2011.

SILVA, W. R. Fragmentação do espaço urbano de Londrina. Revista Geografia, Londrina, v. 10, n. 1, p. 5-14, $\quad$ jan./jun. $2001 . \quad$ Disponível em: <http://www.uel.br/revistas/uel/index.php/geografia/article/view/10210>. Acesso em: 12 dez. 2018.

Para além das cidades - centralidade e estruturação urbana: Londrina e Maringá. 2006. 280 f. Tese (Doutorado em Geografia) - Faculdade de Ciências e Tecnologia, Universidade Estadual Paulista, Presidente Prudente, 2006. 
SOLOMON, S. A grande importância da pequena empresa: a pequena empresa nos Estados Unidos, no Brasil e no mundo. Rio de Janeiro: Nórdica, 1986.

SPOSITO, M. E. B. Capitalismo e urbanização. 14ª ed. São Paulo: Contexto, 1988.

WEBER, M. Conceito e categorias da cidade. Tradução de Antônio Carlos Pinto Peixoto. In: VELHO, O. G. (Org.). Textos básicos de Ciências Sociais - O fenômeno urbano. Rio de Janeiro: Zahar, 1967. p. 7396.

WHITACKER, A. M. Reestruturação urbana e centralidade em São José do Rio Preto - SP. 2003. 238 f. Tese (Doutorado em Geografia) - Faculdade de Ciências e Tecnologia, Universidade Estadual Paulista, Presidente Prudente, 2003.

WIRTH, L. O urbanismo como modo de vida. Tradução de Marina Corrêa Treuherz. In: VELHO, O. G. (Org.). Textos básicos de Ciências Sociais - O fenômeno urbano. Rio de Janeiro: Zahar, 1967. p. 97122.

Recebido em: 19/05/2018

Aceito para publicação em: 09/04/2020 